(C) 2019. This is the pre-print (submitted) version of the following article: "K. Wagner, G. Häggström, A.M. Mauerhofer, M. Kuba, N. Skoglund, M. Öhman, H. Hofbauer, Layer formation on K-feldspar in fluidized bed combustion and gasification of bark and chicken manure, Biomass and Bioenergy. $127 \quad$ (2019) 105251. https://doi.org/10.1016/j.biombioe.2019.05.020.", which has been published in final form at https://doi.org/10.1016/j.biombioe.2019.05.020. This pre-print version is made available under the CC-BY-NC-ND 4.0 license http://creativecommons.org/licenses/by-nc-nd/4.0/.

\title{
Layer Formation on K-feldspar in Fluidized Bed Combustion and Gasification with bark and chicken manure
}

Katharina Wagner ${ }^{a, b,{ }^{*}}$, Gustav Häggström ${ }^{c}$, Anna Magdalena Mauerhofer ${ }^{\mathrm{b}}$, Matthias Kuba $^{\mathrm{a}, \mathrm{b}, \mathrm{c}, \mathrm{d},{ }^{*}, \text { Nils Skoglund }}{ }^{\mathrm{d}}$, Marcus Öhman ${ }^{\mathrm{c}}$, Hermann Hofbauer ${ }^{\mathrm{b}}$

aBioenergy 2020+ GmbH, Wienerstraße 49, A-7540 Güssing, Austria

${ }^{b}$ Institute of Chemical, Environmental \& Bioscience Engineering, TU Wien, Getreidemarkt 9/166, A-1060 Vienna, Austria

${ }^{\mathrm{C} E n e r g y ~ E n g i n e e r i n g, ~ D i v i s i o n ~ o f ~ E n e r g y ~ S c i e n c e, ~ L u l e a ̊ ~ U n i v e r s i t y ~ o f ~ T e c h n o l o g y, ~ S E-971 ~} 87$ Luleå, Sweden

${ }^{\mathrm{d}}$ Thermochemical Energy Conversion Laboratory, Department of Applied Physics and Electronics, Umeå University, SE-901 87 Umeå, Sweden

*Corresponding author: matthias.kuba@bioenergy2020.eu

T: +43 $332242606-156$

$F:+433322$ 42606-199

katharina.wagner@bioenergy2020.eu

$\mathrm{T}:+43$ (3322) 42606-165

$F:+433322$ 42606-199

\section{Abstract}

The layer formation on bed materials in fluidized bed applications is an often-studied phenomenon where most work has focused on combustion but some studies on gasification exists, and direct comparisons of layer formation in combustion and gasification have been 
performed occasionally. The present work provides a thorough comparison of layer formation during combustion and gasification with K-feldspar as bed material using different feedstocks, namely Ca-rich bark; Ca- and P-rich chicken manure; and an admixture of chicken manure with bark. The feedstocks are tested in a $5 \mathrm{~kW}$ bubbling fluidized bed combustor and a $100 \mathrm{~kW}_{\text {th }}$ dual fluidized bed steam gasifier. A reference bed material sample from the industrial biomass combined heat and power plant (CHP) in Senden is used as example for the gasification of bark-rich logging residues. The formed bed particle layers on the bed material surface are characterised using combined scanning electron microscopy and energy-dispersive X-ray spectroscopy; area mappings and line scans are carried out for all samples. The obtained data shows no essential influence of operational mode on the layer formation process. During the combustion and gasification of Ca-rich feedstocks a layer rich in $\mathrm{Ca}$ formed while $\mathrm{K}$ is diffusing out of the layer. The use of $\mathrm{Ca}$ - and P-rich feedstocks inhibited the diffusion of $\mathrm{K}$ and a layer rich in $\mathrm{Ca}$ and also $\mathrm{P}$ formed. The addition of $\mathrm{P}$ to the feedstock by chicken manure therefore changed the underlying layer formation processes.

\section{Keywords}

Fluidized bed, layer formation, K-feldspar, P, combustion, gasification

\section{Highlights}

- Layer formation on K-feldspar is the same during combustion and gasification

- P-rich chicken manure promotes the formation of phosphates in layers

- P-rich chicken manure hinders diffusion of $\mathrm{K}$ out of the $\mathrm{K}$-feldspar particles

\section{Introduction}

The Holocene epoch, which already lasts for more than 11,700 years, is the only state of the earth system to be known of supporting contemporary human societies. Human activities since the age of industrialization are strongly influencing the earth system increasing the risk of destabilization, resulting in a state less hospitable to the development of human societies. Nine planetary boundaries that define a safe operating space for human societies have been defined, as displayed in Figure 1. [1]

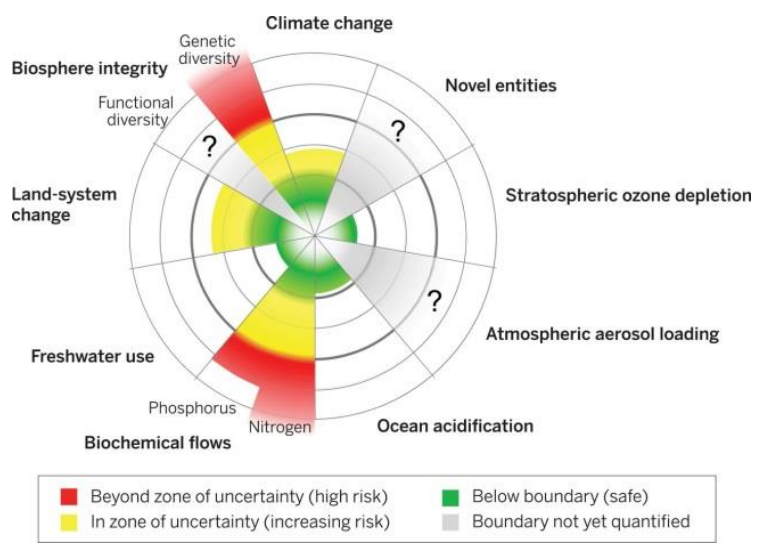

Figure 1. Current status of seven of nine planetary boundaries [1].

60 The biogeochemical flow of $\mathrm{P}$ is one of the planetary boundaries already in a high risk zone. 
80

81

82

83

84

relevant amounts of $\mathrm{P}$ is therefore of major importance. The use of such P-rich waste streams as feedstock in thermochemical conversion applications (e.g. combustion, gasification) is one strategy to address the challenge with biogeochemical flows of $P$ by both reducing waste and enabling recovery and recycling.

Fluidized bed technology is a promising application for such thermochemical conversion of biogenic feedstock. Thermal conversion in fluidized beds allows for utilization of different feedstock [2] and is an industrial established technology. Thermochemical gasification of biogenic feedstock is a promising option to advance the eco-friendly and efficient production of secondary energy carriers, heat and power generation out of the product gas. The dual fluidized bed (DFB) steam gasification of bark-rich logging residues demonstrates a wellproven technology to produce nitrogen-free product gas with a heating value of around 11-15 $\mathrm{MJ} \mathrm{Nm}^{-3}$. The basic principle of the process is shown in Figure 2. This process is based on the separation of endothermic gasification and exothermic combustion. Heat, which is necessary for gasification, is provided by the circulating bed material from the combustion to the gasification reactor. Steam is used as gasification agent for the bubbling bed in the gasification reactor. A part of the biomass is combusted to provide the heat necessary for gasification [3]. A comprehensive review on the DFB gasification technology was recently published by Karl and Pröll [4].

Based on this concept the first industrial application using wood as feedstock was commissioned in the early 2000's with the combined heat and power plant Güssing in Austria (8 $\mathrm{MW}_{\text {th }}$ feedstock capacity). Further plants went into operation in Oberwart/Austria (9 MW fuel capacity), Villach/Austria (15 $\mathrm{MW}_{\text {th }}$ feedstock capacity), Senden/Germany (14 $\mathrm{MW}_{\text {th }}$ feedstock capacity), and in Göteborg/Sweden (32 $\mathrm{MW}_{\text {th }}$ feedstock capacity).

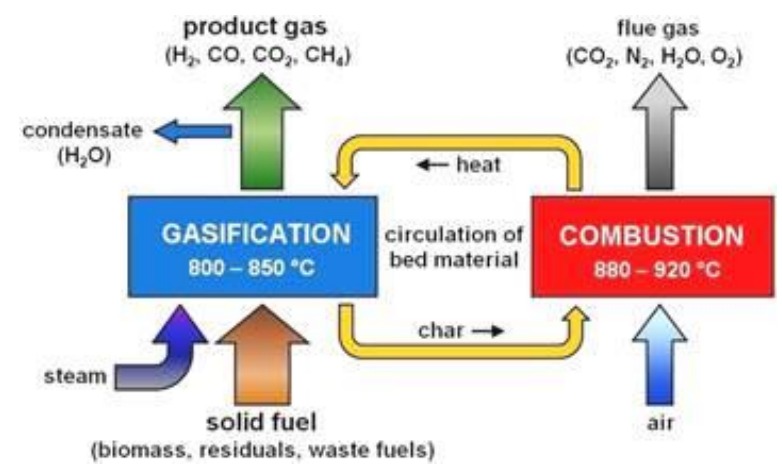

Figure 2. Basic principle of DFB steam gasification [3].

The economic feasibility of biomass projects is highly dependent on the feedstock price. Additionally, biogenic feedstock should not be in competition with food production. To reduce feedstock costs biogenic residues are a promising alternative to woody biomass. One of the challenging issues for the utilization of residues for gasification is the high ash content, which contains various elements. Understanding the ash chemistry in the system is a key factor for further development of the technology [5].

Interactions between feedstock ash and bed material particles have been investigated in the past. Ash layer formation has been described on a mechanistic level for combustion of various feedstocks and for gasification of bark-rich logging residues [2,6-8]. Furthermore, positive catalytic effects have been assigned to Ca-rich ash layers in gasification leading to an improvement of the product gas quality compared to fresh olivine [9,10]. A kinetic rate expression was empirically derived for olivine after an ash-rich layer has formed [11]. 
Berdugo Vilches et al. proposed a first overview of the main transformation reactions pathways of tar species when olivine, activated through interaction with ash components, is used as in-bed catalyst [12]. Optimization of the operation of an industrial-scale DFB steam gasification plant based on the activation of the bed material through interaction with feedstock ash was reported by Kuba et al. [13]. Here, already catalytically activated olivine bed particles were reused in the process to increase the overall activity of the fluidized bed. Similar results regarding the optimization in industrial-scale were obtained at the DFB steam gasifier GoBiGas, where ash components were identified to play a major role in improving the product gas quality [14].

First insights into ash layer formation in both combustion and gasification [15,16] have been reported, indicating that the operational mode has no influence on the layer formation, apart from S-rich feedstocks, where the formation of a melt only occurring during combustion enhances the agglomeration tendency of S-rich feedstocks [15]. The influence of $P$ on the layer formation has been studied in combustion [2] and gasification [17] atmosphere, but to the authors' knowledge no study focused on a comparison of P-rich feedstocks in both combustion and gasification atmosphere. Several groups currently focus on the substitution of olivine as bed material in DFB steam gasification [17-26] due to its heavy metal content [8]. K-feldspar was found as impurity in CHP in Senden, where layers rich in Ca developed and thermochemical analysis showed that these layers show a lower tendency towards agglomeration compared to layers formed on quartz particles [8]. Alkali-feldspar (a mixture of K-feldspar and Na-feldspar, with traces of Ca-feldspar) was shown to have a catalytic activity towards tar reforming [19] and was tested as bed material in the Chalmers 2-MW gasifier [18]. No catalytic activity towards the water-gas-shift reaction was detected for pure Kfeldspar $[17,27]$ but it was possible to activate the K-feldspar by layer formation during the gasification in a $100 \mathrm{~kW}_{\text {th }}$ DFB reactor at TU Wien with a mixture of bark, straw, and chicken manure as feedstock [17].

Therefore, this paper addresses the influence of $P$ on the layer formation both in fluidized bed combustion and gasification with K-feldspar as bed material. Samples from both fluidized bed combustion as well as DFB steam gasification facilities were evaluated. Furthermore, the influence of $P$ from the feedstock regarding layer formation is addressed. For this, P-lean bark, P-rich chicken manure, and an admixture of chicken manure to bark are compared regarding their layer formation process.

\section{Materials and Methods}

Bed material samples were collected from fluidized bed combustion as well as gasification and compared regarding their layer formation. The combustion experiments were carried out in a $5 \mathrm{~kW}$ bubbling fluidized bed reactor. Bed material samples for gasification were obtained from the CHP (15 $\mathrm{MW}_{\text {th }}$ ) in Senden and from a $100 \mathrm{~kW}_{\text {th }}$ DFB pilot plant at TU Wien.

\subsection{Feedstocks}

The feedstocks used for these investigations were conifer bark during combustion and barkrich logging residues for gasification; a mixture of bark with chicken manure (ratio 7:3 dry mass) during combustion and gasification; and pure chicken manure during combustion and gasification. Table 1 shows relevant data for the feedstocks used. The ash content was 
140 determined according to DIN 14775 but at a temperature of $550{ }^{\circ} \mathrm{C}$ and the lower heating

141 value was determined according to DIN 51900 T2.

Table 1. Ash content and LHV of the used feedstocks. The table also gives an overview of the reactors that each feedstock was used in.

\begin{tabular}{|l|l|l|l|}
\hline & & Ash content & $\mathrm{LHV}^{\mathrm{b}}$ \\
\hline Fuel & Used in & $\begin{array}{l}\text { mass } \\
\text { fraction } \\
\text { given in \% } \\
\text { d.b. }\end{array}$ & $\mathrm{kJ} \mathrm{kg}^{\text {a }}($ d.b. \\
\end{tabular}

${ }^{\mathrm{a}}$ dry basis, ${ }^{\mathrm{b}}$ lower heating value

145 Figure 3 shows the feedstock ash components (fuel fingerprint) of the used feedstocks, 146 determined using XRF. Displaying the ash composition in mol kg-1 gives a better overview of 147 the possible interactions taking place in the ash [28]. The used values to obtain Figure 3 are 148 given in the supplementary in Table .

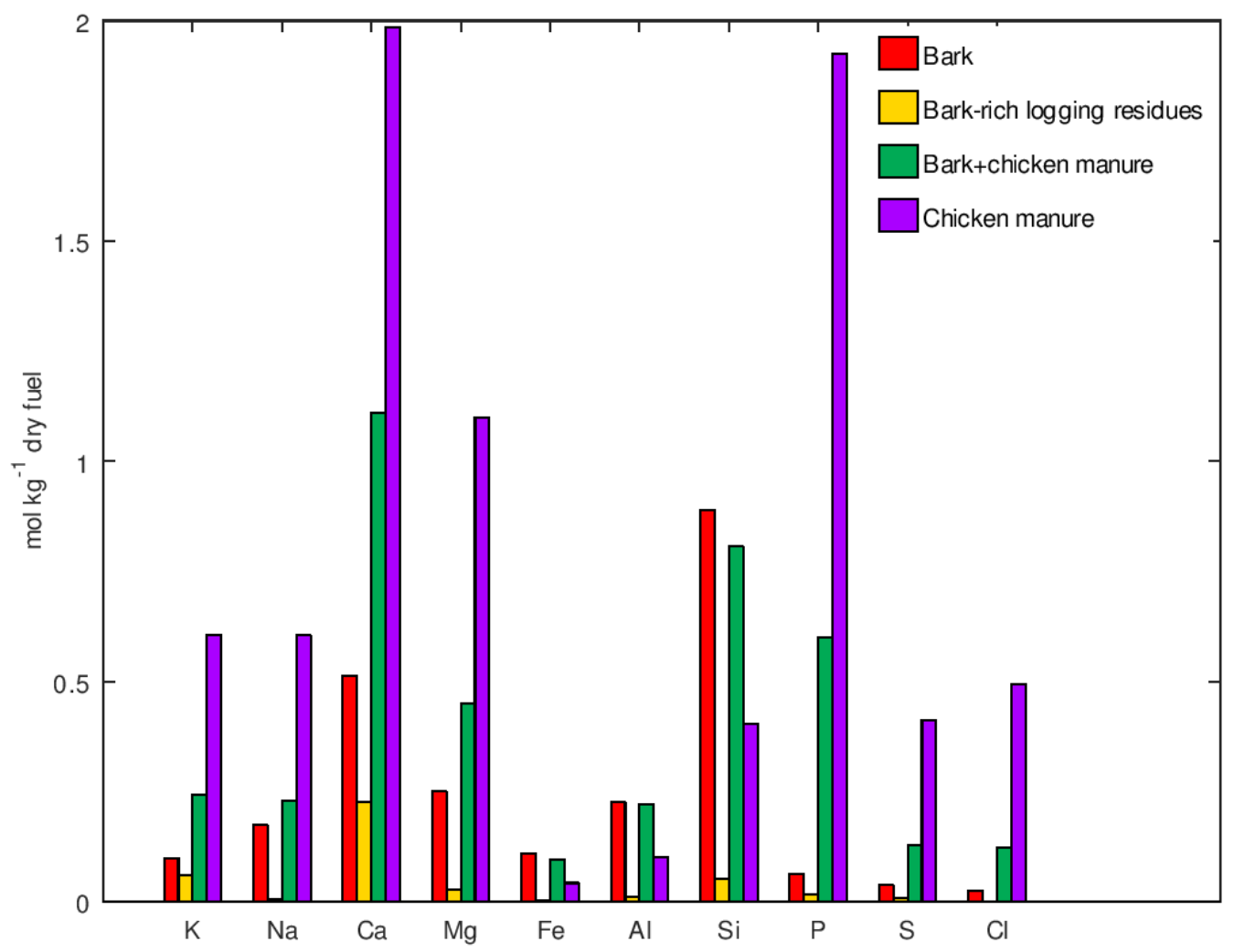

Figure 3. Feedstock ash components in the used feedstocks. 


\subsection{Bed material}

Feldspar is currently investigated comprehensively as bed material for DFB steam gasification [17-19]. K-feldspar has a mohs' hardness of 6 and its density is $2600 \mathrm{~kg} \mathrm{~m}^{-3}$. Additionally, it is an easily available mineral and therefore a promising bed material especially for gasification.

For the combustion experiments in the $5 \mathrm{~kW}$ test rig, K-feldspar was sieved to a particle size of $200-250 \mu \mathrm{m}$ as needed for the bubbling fluidized bed reactor. The K-feldspar studied from the CHP in Senden is an "impurity" introduced with the feedstock into the olivine bed, which is currently used in commercial DFB gasifiers. For the gasification test campaigns in the $100 \mathrm{~kW}$ DFB pilot plant a mixture of $0.89 \mathrm{~kg} \mathrm{~kg}^{-1} \mathrm{~K}$-feldspar $\left(\mathrm{d}_{\mathrm{sv}}=287 \mu \mathrm{m}\right)$ and $0.11 \mathrm{~kg}$ $\mathrm{kg}^{-1}$ limestone $\left(\mathrm{d}_{\mathrm{sv}}=480 \mu \mathrm{m}\right)$ was used. The calcite was added to increase the catalytic activity of the bed during start-up, since the pure and unused K-feldspar does not possess any catalytic activity $[17,27]$.

\subsection{Fluidized bed reactors for experimental investigations}

Combustion experiments were conducted in a $5 \mathrm{~kW}$ bubbling fluidized bed (BFB) reactor. The total height of the reactor is $2 \mathrm{~m}$ with an inner diameter of $100 \mathrm{~mm}$ at the air distribution plate and $200 \mathrm{~mm}$ in the freeboard section. Temperatures and pressures could be monitored continuously. The fluidized bed was maintained with a primary air flow of $50 \mathrm{NL} \mathrm{min}{ }^{-1}$ through the distribution plate below the bed. The primary air velocity was approximately six times the minimum fluidization velocity which translates to about $0.6 \mathrm{~m} \mathrm{~s}^{-1}$. A secondary air flow of 30 $\mathrm{NL} \mathrm{min}^{-1}$ was introduced into the reactor above the fluidized bed into the freeboard providing sufficient oxygen to ensure complete combustion of the generated gases. The reactor was equipped with external heaters for heat up and compensation of heat losses. The temperature inside the reactor is regulated by these heaters as well as by the feedstock input. The flue gas is cleaned by a cyclone removing all particles larger than $10 \mu \mathrm{m}$. Afterwards the flue gas is further cleaned with a water scrubber. A more detailed description can be found elsewhere [29]. In total, $540 \mathrm{~g}$ of the sieved bed material were added to the fluidized bed. The operating temperature during the combustion experiments were around $800{ }^{\circ} \mathrm{C}$ and feedstock was continuously fed with a rate around $0.7 \mathrm{~kg} \mathrm{~h}^{-1}$ for 40 hours or until the bed collapsed due to agglomeration of the bed material. Bed material samples were taken after the experiments and were then further analysed regarding layer formation.

The bed material sample for the gasification of bark-rich logging residues was taken from the CHP in Senden. The studied K-feldspar particles are "impurities" introduced by the feedstock. The data presented in this work is also described in an earlier work [8].

Gasification experiments with bark+chicken manure and chicken manure were conducted in a $100 \mathrm{~kW}_{\text {th }}$ DFB pilot plant at TU Wien. A detailed description on the specific design of the reactor system can be found in literature [30]. For the gasification test campaigns the DFB steam gasifier was first heated up with electrical trace heating and later on additionally by combusting softwood pellets until the desired temperatures were reached. At that point steam fluidization was started in the gasification reactor until a steady-state operation was achieved. During this gasification test campaigns several feedstocks were tested. At first, a benchmark operation with softwood pellets was carried out, further described elsewhere [20]. Afterwards the test campaign with bark+chicken manure pellets was started, before ending with the chicken manure pellets only. Bed material samples were taken before each fuel 
Table 2 summarizes the experiments covered in this work. It gives an overview of the average temperatures observed and the operation time when the samples were taken. For the combustion experiments $T_{\text {combustion }}$ describes the temperature in the fluidized bed, while for the gasification experiments $T_{\text {combustion }}$ describes the temperatures measured in the combustion reactor and $T_{\text {gasification the temperatures in the gasification reactor. The }}$ operational times of the compared experiments differ greatly, as can be seen in Table 2. At this point it is worth mentioning that the combustion experiment with chicken manure did not lead to defluidization but was stopped intentionally due to the accumulating ash inside the system.

Table 2. Average temperatures measured during the operation and duration of operation when the sample was taken.

\begin{tabular}{|l|l|l|l|l|l|l|l|}
\hline & & \multicolumn{3}{|c|}{ Combustion (5 kW) } & \multicolumn{3}{c|}{ Gasification } \\
\hline & & Bark & $\begin{array}{l}\text { Bark+ } \\
\text { chicken } \\
\text { manure }\end{array}$ & $\begin{array}{l}\text { Chicken } \\
\text { manure }\end{array}$ & $\begin{array}{l}\text { Bark-rich } \\
\text { logging } \\
\text { residues } \\
(15 \mathrm{MW})[8]\end{array}$ & $\begin{array}{l}\text { Bark+ } \\
\text { chicken } \\
\text { manure } \\
(100 \mathrm{~kW})\end{array}$ & $\begin{array}{l}\text { Chicken } \\
\text { manure } \\
(100 \\
\mathrm{kW})\end{array}$ \\
\hline $\mathrm{T}_{\text {combustion }}$ & ${ }^{\circ} \mathrm{C}$ & 826 & 795 & 804 & 884 & 996 & 952 \\
\hline $\mathrm{T}_{\text {gasitication }}$ & ${ }^{\circ} \mathrm{C}$ & n.a. $^{\mathrm{a}}$ & n.a. $^{\mathrm{a}}$ & $\mathrm{n} \mathrm{a}^{\mathrm{a}}$ & 856 & 777 & 766 \\
\hline $\mathrm{t}_{\text {operation }}$ & $\mathrm{h}$ & 36.5 & 40 & 10.8 & $\begin{array}{l}\text { Constant bed } \\
\text { replacement }\end{array}$ & 2.9 & 1.9 \\
\hline
\end{tabular}

${ }^{a}$ not applicable

\subsection{Scanning electron microscopy with energy dispersive spectroscopy}

For all analyses, the materials were mounted in epoxy and polished to obtain cross sections of bed particles. Combined scanning electron microscope (SEM) and energy-dispersive Xray spectroscopy (EDS) area mappings and line scans were applied to study the bed materials. Layer morphology in the samples was determined with a Zeiss Evo LS-15 at a voltage of $20 \mathrm{kV}$ and a current of $400 \mathrm{pA}$ in backscattered mode; elemental composition was determined using an Oxford X-MaxN 80 EDS detector. Overview images were captured to identify typical bed particles for elemental analysis. In each sample, around 30 line scans distributed over several particles and approximately five area mappings were obtained.

\section{Results and Discussion}

Table 3 depicts SEM images and EDS measurements obtained for the samples of the experiments. The SEM images show, that an observable layer formed for all experiments. The EDS measurements show, that during all experiments layers rich in Ca were formed. P was only found in the layers if a P-rich feedstock was used. During the combustion experiments with bark+chicken manure and chicken manure $S$ was non-continuously detected in layers as well. The observed composition of these S-containing areas corresponds to analyses done for ash particles found in the bed, which will be the focus of an upcoming work.

Figure 4 shows a close-up of a K-feldspar particle obtained from the combustion of bark+chicken manure and Table 4 shows corresponding EDS images. A clear layer 
229 formation can be observed in the micrograph. The cracks in the layer probably stem from the 230 preparation of the sample since no differences in elemental composition along the cracks are 231 observable in the EDS images. The EDS images clearly show that $\mathrm{Ca}$ is found further into 232 the particle compared to $\mathrm{Mg}$ and phosphorous.

233 Table 3. SEM and EDS analysis of K-feldspar particles for the experiments with bark, bark+chicken 234 manure, and chicken manure in combustion and gasification atmosphere.

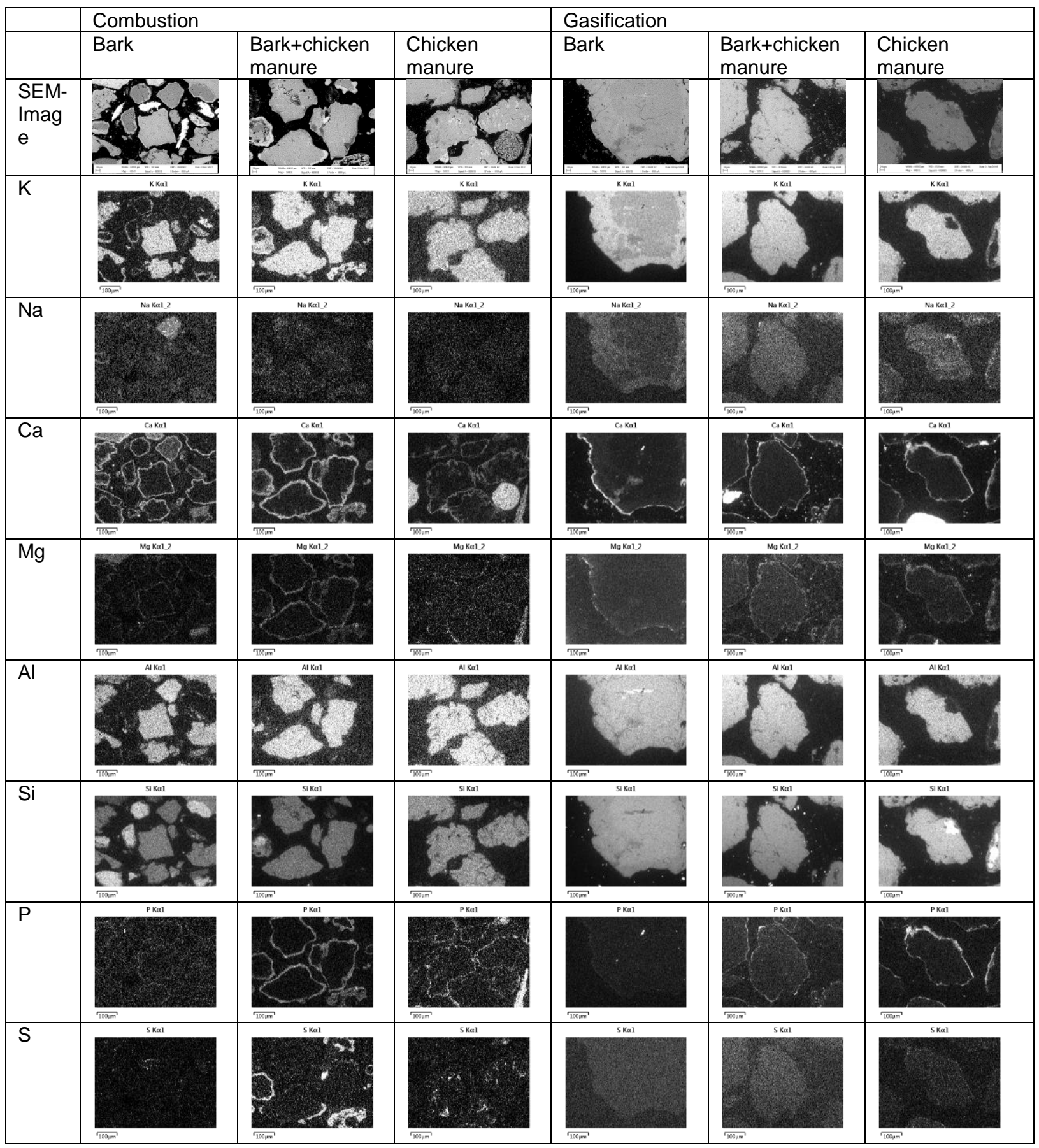




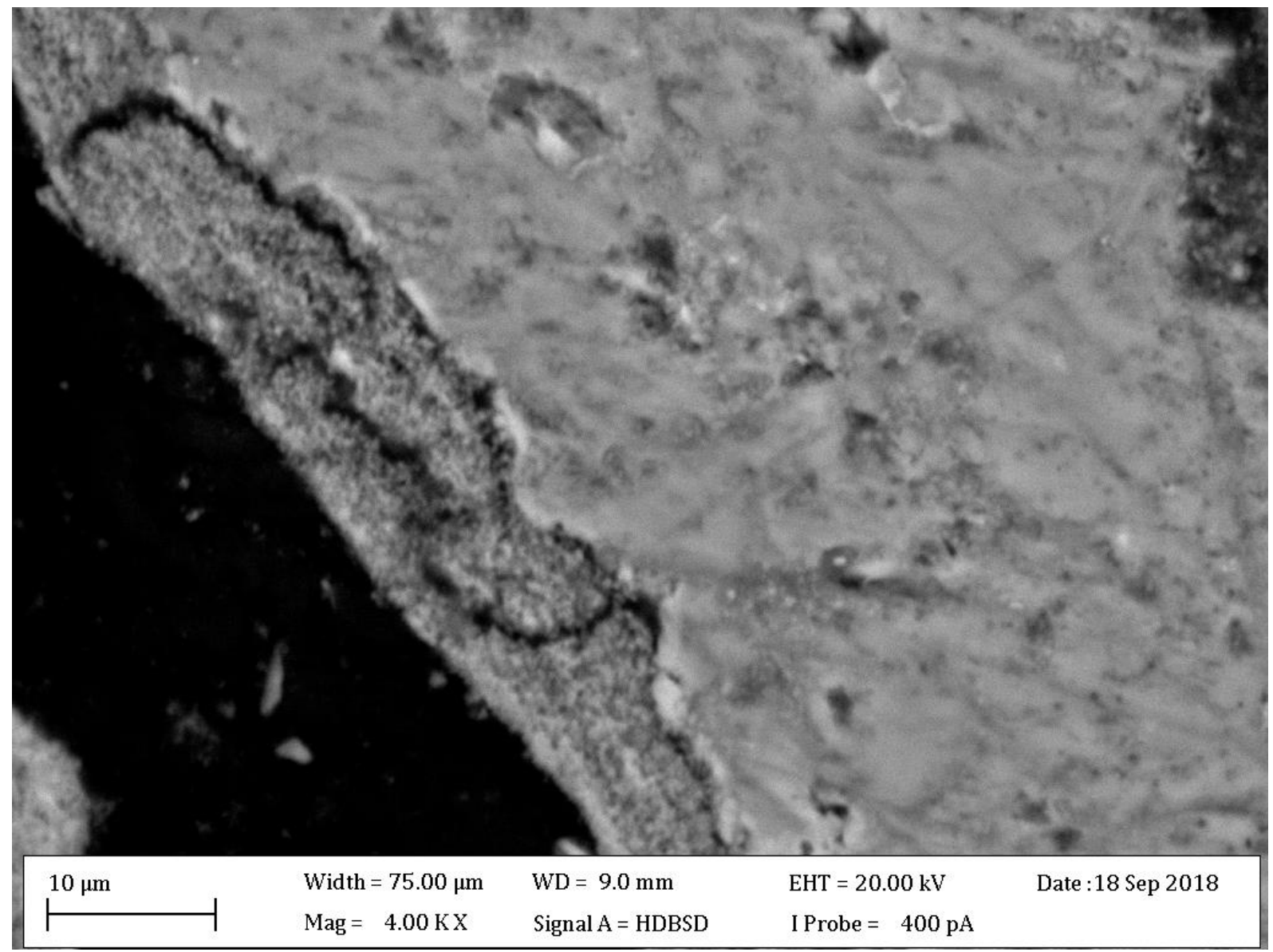

Figure 4. Close-up of K-feldspar obtained after the combustion with bark+chicken manure. 
Table 4. EDS images of K-feldspar obtained after the combustion with bark+chicken manure.

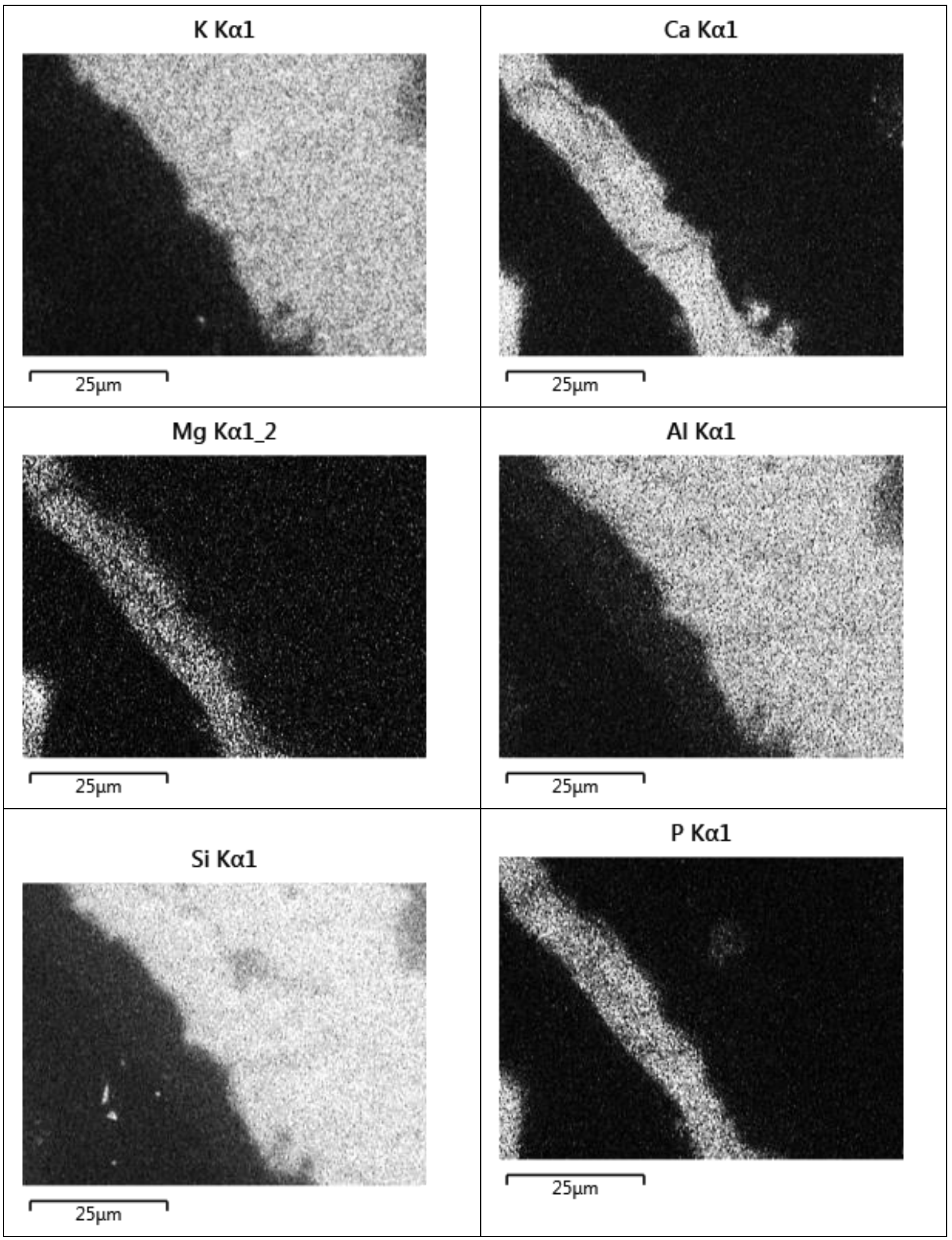


Figure 5 shows exemplary line scans for all experiments. Line scan a) shows the developed line after the combustion of bark. It can be seen that the concentration of $\mathrm{Ca}$ is increasing towards the surface, while $\mathrm{K}$ is depleted. This can be seen by the deviation of the inherent $\mathrm{K}$ feldspar K/Al ratio of 1 to 0.22 in the layers formed. This substitution of $\mathrm{K}$ by $\mathrm{Ca}$ is typical for woody biomass ash interacting with K-feldspar [8,31]. Apart from $\mathrm{Ca}$ and the elements naturally contained in $\mathrm{K}$-feldspar only $\mathrm{Mg}$ is found in a relevant amount. The line scan measured for K-feldspar found in the sample for the gasification of bark-rich logging residues is depicted in Figure $5 \mathrm{~b}$ ). Similarly to the results observed for the combustion of bark, an enrichment with $\mathrm{Ca}$ was detected while $\mathrm{K}$ is depleted. The depletion can again be characterized by a $\mathrm{K} / \mathrm{Al}$ ratio of 0.62 . For this sample no $\mathrm{Mg}$ was observed in the layer.

Even though K-feldspar was only contained as an "impurity" in the olivine bed used for the gasification of bark-rich logging residues at the CHP in Senden, the same layer formation process took place also when no olivine was present. It is therefore possible to study the layer formation on "impurities" and assume that the same process is occurring for a pure bed.

a)

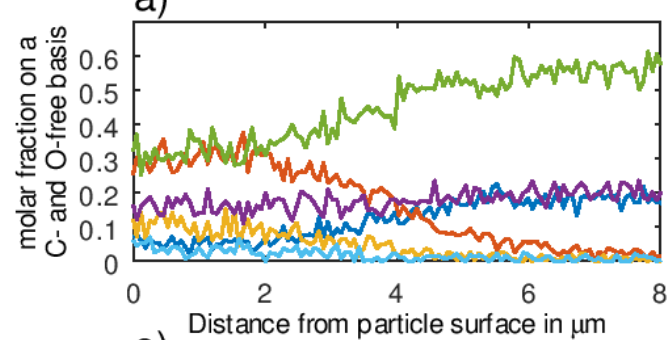

c)

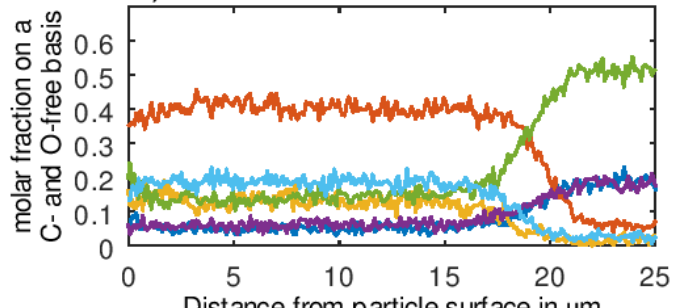

e)

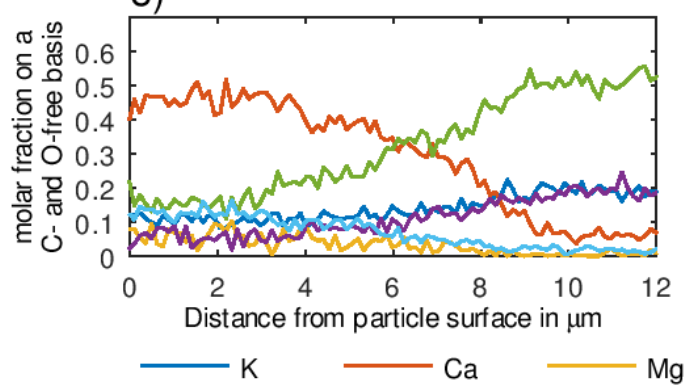

b)

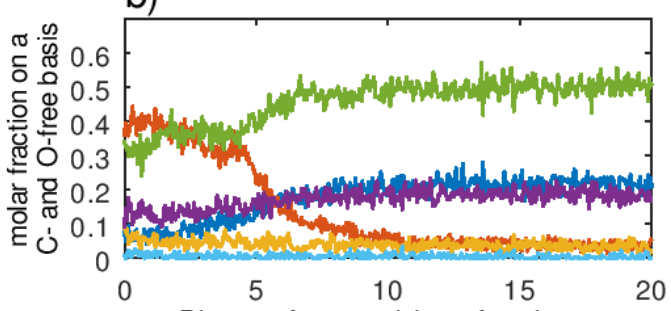

d)
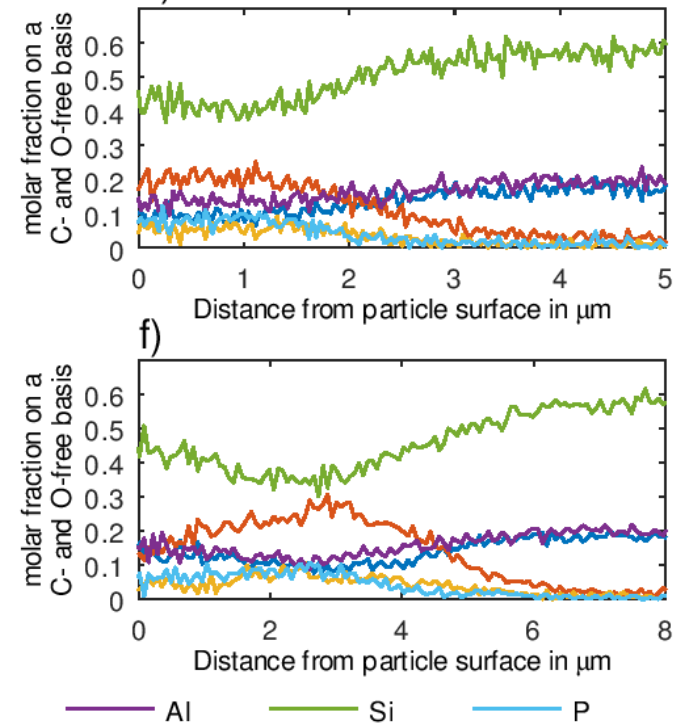

Figure 5. Linescans measured on K-feldspar. The given distance starts at the outside of the particle and points towards the core. a) Combustion of bark b) Gasification of bark-rich logging residues c) Combustion of bark+chicken manure d) Gasification of bark+chicken manure e) Combustion of chicken manure f) Gasification of chicken manure.

The layer formed during the combustion of bark+chicken manure, depicted in Figure $5 \mathrm{c}$ ) is mainly dominated by $\mathrm{Ca}, \mathrm{P}$, and $\mathrm{Mg}$. As already observed in Table $4 \mathrm{Ca}$ seems to be found further into K-feldspar compared to $\mathrm{Mg}$ and $\mathrm{P}$. The same can be said for the layer formed during the gasification of bark+chicken manure, Figure $5 \mathrm{~d}$ ). Even though the layer is thinner, $\mathrm{Ca}$ is again measured further into the particle compared to $\mathrm{P}$ and $\mathrm{Mg}$. Apart from these three 
elements no other elements could be found in a relevant amount. A similar observation can be made for the layers studied after the combustion and gasification of chicken manure, seen in Figure $5 \mathrm{e}$ ) and f), respectively. $\mathrm{Ca}$ is again found further into the particle, while $\mathrm{P}$ and $\mathrm{Mg}$ are enriched in the layer at the same location and no $\mathrm{K}$ depletion is occurring. The continued use of the bed material after the gasification of bark+chicken manure does not seem to have an influence on the formed layer during the gasification of chicken manure. This can be said, since no two separate layers different in composition were observed in the case for chicken manure, but only one layer which is similar in composition to the combustion of chicken manure. For the experiments with bark+chicken manure and pure chicken manure no depletion of $\mathrm{K}$ could be detected.

\subsection{Layer formation process proposal}

A first proposal for a possible layer formation mechanism will be given in the following section based on the data presented throughout this work. To further support the following proposal experiments focusing on long-term operation will be necessary.

The layers formed for bark+chicken manure and pure chicken manure are different to the layers formed with bark and bark-rich logging residue but similar to each other. For those experiments, the diffusion of $\mathrm{K}$ out of the $\mathrm{K}$-feldspar cannot be detected. This is due to the fact that the high levels of phosphorous for bark+chicken manure and chicken manure shift the reactions into the ash phase to the formation of Ca-rich phosphates. This effect is already observable for an admixture of chicken manure of 0.3 dry mass fraction as studied here. That is due to the fact that chicken manure has a comparably high ash content, see Table 1 and Figure 3 , so small admixtures already highly influence the ash chemistry. The often overlooked high $\mathrm{Ca}$ content of chicken manure is additionally influencing the ash chemistry. This high $\mathrm{Ca}$ content is promoting the formation of Ca-rich layers, which are known to be catalytically active for gasification reactions [10], also when phosphorous is present in the layers [17].

All line scans with bark show that $\mathrm{Ca}$ is penetrating further into the particle than $\mathrm{P}$. This is likely due to the formation of an inner and an outer layer. If the ratio of $\mathrm{P}$ to $\mathrm{Ca}$ is further increased it was previously speculated that the inner layer might be completely inhibited. This is explained in the following. The inner layer is formed by the diffusion of $\mathrm{Ca}$ into the particle, while the outer layer is formed by adhesion of ash, resulting in high shares of $\mathrm{Ca}$ and $P$, which form the majority of chicken manure ash. Grimm et al. [2] have observed an inhibition of inner layer formation when using P-rich sewage sludge as feedstock and quartz particles as bed material in fluidized bed combustion experiments. The inhibition of the inner layer was explained by phosphate formation within the ash, which further leads to less reactivity of the ash components with the bed particle itself.

Figure 6 shows a simple scheme of inner and outer layer formation. Inner layer formation is characterized by a chemical reaction-based interaction between feedstock ash components and the bed particle surface. This interaction can be e.g. alkali-silicate formation, as observed for quartz where $\mathrm{K}$ reacts with silicon to form K-silicates [32]. Furthermore, inner layer formation can be based on a substitution reaction, as observed for olivine where $\mathrm{Ca}^{2+}$ ions substitute $\mathrm{Fe}^{2+}$ and $\mathrm{Mg}^{2+}$ ions in the crystal structure of olivine. Therefore, inner layers typically grow inwards into the bed particles [33].

Outer layers, on the other hand, are formed through accumulation of ash components on the particle surface and pile up outwards. Woody feedstock typically shows both inner and outer 


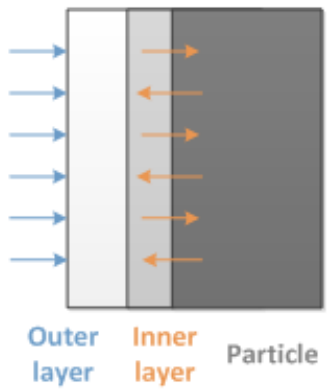

a)

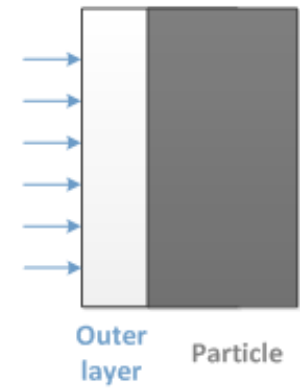

b)

Figure 6. Simple scheme of layer formation mechanisms; a) Chemical reaction-based layer formation with woody-based feedstock, b) Ash accumulation-based layer formation with P-rich feedstock.

Frequently proposed mechanisms for layer formation in the literature [32,33] typically refer to inner layer formation since outer layers are merely an accumulation of ash components and therefore highly dependent on the feedstock ash content itself.

Inner layer formation has been observed to be an important factor in agglomeration in fluidized beds, as coating- or layer-induced agglomeration is a major issue when quartz particles are used as bed material [34-36]. Since outer layers are typically dominant in $\mathrm{Ca}$ the agglomeration tendency decreases once an outer layer - acting as a shell around the particle and, if applicable, the inner layer - has been formed. Furthermore, Ca from the outer layer can diffuse to and react with the inner e.g. K-rich layer forming a more Ca-rich inner layer with higher melting temperature. Thus, layer formation is of high relevance when it comes to investigation on agglomeration processes.

\section{Conclusion}

The presented results show that layer formation on K-feldspar is mainly dependent on the used feedstock and findings for BFB combustion and DFB gasification were similar to each other. When feedstocks rich in $\mathrm{P}$ are being used, an enrichment of $\mathrm{P}$ in the layer could be observed. Due to this it is possible to adapt the observations regarding layer formation collected for combustion to gasification applications. It was furthermore speculated that an increased $P$ content hinders the formation of inner layers by promoting the formation of phosphates in the ash fraction. The formed phosphates then stick to the K-feldspar particles to form an ash-rich layer. This ash-rich layer forms independent of the atmosphere, i.e. combustion or gasification.

\section{Acknowledgments}

This study was carried out in the frame of the Bioenergy2020+ projects "C200410" and "N200560". Bioenergy2020+ GmbH is funded within the Austrian COMET program, which is managed by the Austrian Research Promotion Agency (FFG) and promoted by the federal 
332 government of Austria as well as the federal states of Burgenland, Niederösterreich and 333 Steiermark.

334 Furthermore, we thank FORMAS Mobility Grant No. 2017-01613 and National Swedish 335 Strategic Research programme Bio4Energy, Thermochemical Conversion Technologies 336 Platform and Platform for Environment and Nutrient Recycling. We also thank the facilities 337 and technical support (Cheng Choo Lee) of the Umeå Core Facility for Electron Microscopy 338 (UCEM) at the Chemical Biological Centre (KBC), Umeå University. 


\section{References}

[1] W. Steffen, K. Richardson, J. Rockström, S.E. Cornell, I. Fetzer, E.M. Bennett, R. Biggs, S.R. Carpenter, W. de Vries, C.A. de Wit, C. Folke, D. Gerten, J. Heinke, G.M. Mace, L.M. Persson, V. Ramanathan, B. Reyers, S. Sörlin, Planetary boundaries: Guiding human development on a changing planet, Science. 347 (2015) 1259855. doi:10.1126/science.1259855.

[2] A. Grimm, N. Skoglund, D. Boström, M. Öhman, Bed Agglomeration Characteristics in Fluidized Quartz Bed Combustion of Phosphorus-Rich Biomass Fuels, Energy Fuels. 25 (2011) 937-947. doi:10.1021/ef101451e.

[3] J.C. Schmid, U. Wolfesberger, S. Koppatz, C. Pfeifer, H. Hofbauer, Variation of feedstock in a dual fluidized bed steam gasifier-influence on product gas, tar content, and composition, Environ. Prog. Sustain. Energy. 31 (2012) 205-215. doi:10.1002/ep.11607.

[4] J. Karl, T. Pröll, Steam gasification of biomass in dual fluidized bed gasifiers: A review, Renew. Sustain. Energy Rev. 98 (2018) 64-78. doi:10.1016/j.rser.2018.09.010.

[5] D. Boström, N. Skoglund, A. Grimm, C. Boman, M. Öhman, M. Broström, R. Backman, Ash Transformation Chemistry during Combustion of Biomass, Energy Fuels. 26 (2012) 85-93. doi:10.1021/ef201205b.

[6] H. He, D. Boström, M. Öhman, Time Dependence of Bed Particle Layer Formation in Fluidized Quartz Bed Combustion of Wood-Derived Fuels, Energy Fuels. 28 (2014) 3841-3848. doi:10.1021/ef500386k.

[7] F. Kirnbauer, H. Hofbauer, Investigations on Bed Material Changes in a Dual Fluidized Bed Steam Gasification Plant in Güssing, Austria, Energy Fuels. 25 (2011) 3793-3798. doi:10.1021/ef200746c.

[8] M. Kuba, H. He, F. Kirnbauer, N. Skoglund, D. Boström, M. Öhman, H. Hofbauer, Thermal Stability of Bed Particle Layers on Naturally Occurring Minerals from Dual Fluid Bed Gasification of Woody Biomass, Energy Fuels. 30 (2016) 8277-8285. doi:10.1021/acs.energyfuels.6b01523.

[9] F. Kirnbauer, V. Wilk, H. Kitzler, S. Kern, H. Hofbauer, The positive effects of bed material coating on tar reduction in a dual fluidized bed gasifier, Fuel. 95 (2012) 553562. doi:10.1016/j.fuel.2011.10.066.

[10] M. Kuba, F. Havlik, F. Kirnbauer, H. Hofbauer, Influence of bed material coatings on the water-gas-shift reaction and steam reforming of toluene as tar model compound of biomass gasification, Biomass Bioenergy. $89 \quad$ (2016) 40-49. doi:10.1016/j.biombioe.2015.11.029.

[11] J. Kryca, J. Priščák, J. Łojewska, M. Kuba, H. Hofbauer, Apparent kinetics of the watergas-shift reaction in biomass gasification using ash-layered olivine as catalyst, Chem. Eng. J. 346 (2018) 113-119. doi:10.1016/j.cej.2018.04.032.

[12] T. Berdugo Vilches, M.C. Seemann, H. Thunman, Influence of in-bed catalysis by ashcoated olivine on tar formation in steam gasification of biomass, Energy Fuels. (2018). doi:10.1021/acs.energyfuels.8b02153.

[13] M. Kuba, S. Kraft, F. Kirnbauer, F. Maierhans, H. Hofbauer, Influence of controlled handling of solid inorganic materials and design changes on the product gas quality in dual fluid bed gasification of woody biomass, Appl. Energy. 210 (2018) 230-240. doi:10.1016/j.apenergy.2017.11.028.

[14] H. Thunman, M. Seemann, T.B. Vilches, J. Maric, D. Pallares, H. Ström, G. Berndes, P. Knutsson, A. Larsson, C. Breitholtz, O. Santos, Advanced biofuel production via gasification - lessons learned from 200 man-years of research activity with Chalmers' research gasifier and the GoBiGas demonstration plant, Energy Sci. Eng. 6 (2018) 634. doi:10.1002/ese3.188.

[15] M. Öhman, L. Pommer, A. Nordin, Bed Agglomeration Characteristics and Mechanisms during Gasification and Combustion of Biomass Fuels, Energy Fuels. 19 (2005) 17421748. doi:10.1021/ef040093w. 
[16] Z. He, D.J. Lane, W.L. Saw, P.J. van Eyk, G.J. Nathan, P.J. Ashman, Ash-Bed Material Interaction during the Combustion and Steam Gasification of Australian Agricultural Residues, Energy Fuels. 32 (2018) 4278-4290. doi:10.1021/acs.energyfuels.7b03129.

[17] K. Wagner, A.M. Mauerhofer, M. Kuba, H. Hofbauer, Suitability of K-feldspar as Alternative Bed Material in Dual Fluidized Bed Steam Gasification in Combination with Ash-Rich Feedstocks, in: 23rd Int. Conf. FBC, Seoul, Korea, 2018: pp. 967-976.

[18] N. Berguerand, T. Berdugo Vilches, Alkali-Feldspar as a Catalyst for Biomass Gasification in a 2-MW Indirect Gasifier, Energy Fuels. 31 (2017) 1583-1592. doi:10.1021/acs.energyfuels.6b02312.

[19] N. Berguerand, J. Marinkovic, T. Berdugo Vilches, H. Thunman, Use of alkali-feldspar as bed material for upgrading a biomass-derived producer gas from a gasifier, Chem. Eng. J. 295 (2016) 80-91. doi:10.1016/j.cej.2016.02.060.

[20] A.M. Mauerhofer, F. Benedikt, J.C. Schmid, J. Fuchs, S. Müller, H. Hofbauer, Influence of different bed material mixtures on dual fluidized bed steam gasification, Energy. 157 (2018) 957-968. doi:10.1016/j.energy.2018.05.158.

[21] A. Magdalena Mauerhofer, F. Benedikt, J. Christian Schmid, H. Hofbauer, Mixtures of Silica Sand and Calcite as Bed Material for Dual Fluidized Bed Steam Gasification, in: Proc. SEEP2017, University of Maribor Press, 2017: pp. 253-266. doi:10.18690/978961-286-048-6.26.

[22] C. Pfeifer, S. Koppatz, H. Hofbauer, Catalysts for dual fluidised bed biomass gasification-an experimental study at the pilot plant scale, Biomass Convers. Biorefinery. 1 (2011) 63-74. doi:10.1007/s13399-011-0005-3.

[23] C. Pfeifer, S. Koppatz, H. Hofbauer, Steam gasification of various feedstocks at a dual fluidised bed gasifier: Impacts of operation conditions and bed materials, Biomass Convers. Biorefinery. 1 (2011) 39-53. doi:10.1007/s13399-011-0007-1.

[24] T. Berdugo Vilches, J. Marinkovic, M. Seemann, H. Thunman, Comparing Active Bed Materials in a Dual Fluidized Bed Biomass Gasifier: Olivine, Bauxite, Quartz-Sand, and IImenite, Energy Fuels. 30 (2016) 4848-4857. doi:10.1021/acs.energyfuels.6b00327.

[25] J. Marinkovic, M. Seemann, G.L. Schwebel, H. Thunman, Impact of Biomass AshBauxite Bed Interactions on an Indirect Biomass Gasifier, Energy Fuels. 30 (2016) 4044-4052. doi:10.1021/acs.energyfuels.6b00157.

[26] S. Anis, Z.A. Zainal, Tar reduction in biomass producer gas via mechanical, catalytic and thermal methods: A review, Renew. Sustain. Energy Rev. 15 (2011) 2355-2377. doi:10.1016/j.rser.2011.02.018.

[27] M. Kuba, F. Kirnbauer, H. Hofbauer, Influence of coated olivine on the conversion of intermediate products from decomposition of biomass tars during gasification, Biomass Convers. Biorefinery. 7 (2017) 11-21. doi:10.1007/s13399-016-0204-z.

[28] N. Skoglund, Ash chemistry and fuel design focusing on combustion of phosphorus-rich biomass, Doctoral Thesis, Department of applied physics and electronics, Umeå universitet, 2014.

[29] M. Öhman, A. Nordin, A New Method for Quantification of Fluidized Bed Agglomeration Tendencies: A Sensitivity Analysis, Energy Fuels. 12 (1998) 90-94. doi:10.1021/ef970049z.

[30] J.C. Schmid, Development of a novel dual fluidized bed gasification system for increased fuel flexibility, PhD Thesis, Doctoral thesis, Institute of Chemical Engineering, Vienna University of Technology, 2014.

[31] H. He, N. Skoglund, M. Öhman, Time-Dependent Layer Formation on K-Feldspar Bed Particles during Fluidized Bed Combustion of Woody Fuels, Energy Fuels. 31 (2017) 12848-12856. doi:10.1021/acs.energyfuels.7b02386.

[32] H. He, X. Ji, D. Boström, R. Backman, M. Öhman, Mechanism of Quartz Bed Particle Layer Formation in Fluidized Bed Combustion of Wood-Derived Fuels, Energy Fuels. 30 (2016) 2227-2232. doi:10.1021/acs.energyfuels.5b02891.

[33] M. Kuba, H. He, F. Kirnbauer, N. Skoglund, D. Boström, M. Öhman, H. Hofbauer, Mechanism of Layer Formation on Olivine Bed Particles in Industrial-Scale Dual Fluid Bed Gasification of Wood, Energy Fuels. 30 (2016) 7410-7418. doi:10.1021/acs.energyfuels.6b01522. 
[34] H.J.M. Visser, S.C. van Lith, J.H.A. Kiel, Biomass Ash-Bed Material Interactions Leading to Agglomeration in FBC, J. Energy Resour. Technol. 130 (2008) 011801. doi:10.1115/1.2824247.

[35] M. Öhman, A. Nordin, B.-J. Skrifvars, R. Backman, M. Hupa, Bed Agglomeration Characteristics during Fluidized Bed Combustion of Biomass Fuels, Energy Fuels. 14 (2000) 169-178. doi:10.1021/ef990107b.

[36] F. Scala, Particle agglomeration during fluidized bed combustion: Mechanisms, early detection and possible countermeasures, Fuel Process. Technol. 171 (2018) 31-38. doi:10.1016/j.fuproc.2017.11.001.

\section{Supplementary}

Table A.1. Fuel fingerprint data; concentrations given in $\mathbf{m o l} \mathbf{~ k g}^{-1}$.

\begin{tabular}{|l|l|l|l|l|l|l|l|l|l|l|}
\hline & $\mathrm{K}$ & $\mathrm{Na}$ & $\mathrm{Ca}$ & $\mathrm{Mg}$ & $\mathrm{Fe}$ & $\mathrm{Al}$ & $\mathrm{Si}$ & $\mathrm{P}$ & $\mathrm{S}$ & $\mathrm{Cl}$ \\
\hline Bark & 0.10 & 0.17 & 0.51 & 0.25 & 0.11 & 0.23 & 0.89 & 0.06 & 0.04 & 0.02 \\
\hline $\begin{array}{l}\text { Bark- } \\
\text { rich } \\
\text { logging } \\
\text { residues }\end{array}$ & 0.06 & 0.01 & 0.23 & 0.03 & 0.00 & 0.01 & 0.05 & 0.02 & 0.01 & 0.00 \\
\hline $\begin{array}{l}\text { Bark+ } \\
\text { chicken } \\
\text { manure }\end{array}$ & 0.24 & 0.23 & 1.11 & 0.45 & 0.10 & 0.22 & 0.81 & 0.60 & 0.13 & 0.12 \\
\hline $\begin{array}{l}\text { Chicken } \\
\text { manure }\end{array}$ & 0.60 & 0.60 & 1.99 & 1.10 & 0.04 & 0.10 & 0.40 & 1.92 & 0.41 & 0.49 \\
\hline
\end{tabular}

